\section{General Hertzog and the South African Protectorates}

General Hertzog, Prime Minister of the Union of South Africa, on his return to South Africa from attending the recent Imperial Conference in London, once more raised publicly the question of the transfer of the administration of the native Protectorates in South Africa from the Imperial Government to the Government of the Union. According to a message, which appeared in The Times of July 7 , he alleged that the British Government has failed to carry out pledges of early transfer, which were not only conreyed to him personally by the responsible minister on several occasions, but also were embodied in the agreement which formed the substance of the aidemémoire framed and made public in 1935 . He went on to assert that instructions issued by the British Government to its administrative officials in the Protectorates have failed to carry out an undertaking to direct those officials to bring their influence to bear on the natives in such a manner as to induce in them an attitude favourable to the transfer to the Union.

Mr. Malcolm MacDonald, Secretary of State'for Dominion Affairs, lost no time in his reply to General Hertzog's criticisms. In a statement to the House of Commons on July 9, he made it clear that not only was there no agreement that transfer would take place within a specified time, but also that when General Hertzog had urged upon him in a personal interview that transfer should begin in the near future, he had pointed out in his reply that the situation described in the aide-mémoire had not greatly altered. Further, he went on to indicate that General Hertzog has been kept fully advised of developments in the matter of the Protectorates, not least of the terms of the instructions issued to officials, in which he has fully coneurred. Not only did Mr. MacDonald's action meet with the full approval of the House, but also his further reiteration of the pledge that no action in the matter of transfer would be taken without previous consultation of the inhabitants of the Protectorates received its full endorsement.

\section{Grassland Management in Great Britain}

IN his presidential address delivered on July 14 to the Fourth International Grassland Congress held at Aberystwyth, Prof. R. G. Stapledon gave an interesting summary of his views concerning the approach to grassland problems in general and also in relation to the special circumstances of grassland management in Great Britain. The most hopeful line of attack on the general problem, Prof. Stapledon believes, is by employment of the regional survey method, as developed by the Aberystwyth workers in their treatment of the grasslands of Wales. The procedure is to map, classify and plan on the basis of natural regions; adapting to each the correct type of implements, fertilizers and especially the correct strains of seeds. The breeding of herbage plants should be carried out in the area for which they are intended, and interchange of genes between different countries is more likely to be fruitful than interchange of seeds. Of the many factors concerned in the making of useful grassland, the animal is by far the most important; next comes the leguminous plant. Improvement in many instances consists in setting up such soil conditions that a suitable legume will grow, and then adopting a system of management to favour the legume as well as the grazing animal. Then follows the possibility of growing superior herbage plants that had never succeeded before in that area.

Turning now to some of the special problems of grassland farming in Great Britain, Prof. Stapledon. made a strong case for the use of the plough on grassland wherever possible. The method should be to graze hard before breaking up with the view of laying up a store of organic manure or 'stock nitrogen' in the soil. After ploughing a dressing of lime is given, and the accumulated fertility is then in shape to be cashed in the form of some arable crop or immediately put back into still better pasture. Another point of the greatest importance is the production of out-of-season keep. Much has been done lately to conserve summer grass in dried form for winter feeding, but some progress has been made in growing good quality fresh grass for use between December and March. It is a case of species and management. Choosing winter green strains of plants, the grass is heavily manured through the growing stock, further assisted by a little mineral nitrogen, and rested from the end of summer onwards. Working in this way, the Aberystwyth workers have secured on occasions as much as $1 \frac{1}{2}$ tons of dry matter per acre with 14-20 per cent of crude protein between Christmas and the end of March. Here again young leys offer more possibilities than permanent pasture.

\section{Archæological Excavations at Tell Duweir, 1936-37}

As exhibition of antiquities from Tell Duweir, the ancient Lachish, in Palestine, opened at the Wellcome Research Institution, Euston Road, London, N.W.1, on July 12. These antiquities, with an extensive series of photographs of the site and of the work of excavation in progress, represent the results obtained by the Wellcome-Marston Archæologieal Research Expedition to the Near East in the season 1936-37. The excavations were again under the direction of Mr. J. L. Starkey. The operations of the season were directed mainly to the investigation of three areas-the north-east corner of the mound on ground rising from the valley to the level of the moat of the Hyksos period; the great rock-cut excavation of shaft discovered in 1935, now ascertained to measure eighty-five feet long by seventy feet broad, with a depth of ninety feet; and the area lying behind the south-west gate, with the rising ground to the east reaching up to the walls of the Jewish palace. In the last-named area, water-borne deposits on the ancient roadway as it descends sharply on approaching the threshold of the inner gate, which had been due to the blocking of the 